\title{
Comparative study of a vitrinite-rich and an inertinite-rich Witbank coal (South Africa) using pyrolysis-gas chromatography
}

\author{
Ofentse M. Moroeng ${ }^{1}$ (D) Vimbai Mhuka ${ }^{2} \cdot$ Mathew M. Nindi $^{2} \cdot$ R. James Roberts ${ }^{3}$. \\ Nicola J. Wagner ${ }^{1}$
}

Received: 7 March 2019/Revised: 6 August 2019/Accepted: 12 September 2019/Published online: 15 October 2019

(C) The Author(s) 2019

\begin{abstract}
This study aims to compare iso-rank vitrinite-rich and inertinite-rich coal samples to understand the impact of coal-forming processes on pyrolysis chemistry. A medium rank $\mathrm{C}$ bituminous coal was density-fractionated to create a vitrinite-rich and an inertinite-rich sub-sample. The vitrinite-rich sample has 83 vol\% total vitrinite (mineral-matter-free basis), whereas the inertinite-rich counterpart has 66 vol\% total inertinite. The vitrinite-rich sample is dominated by collotelinite and collodetrinite. Fusinite, semifusinite, and inertodetrinite are the main macerals of the inertinite-rich sample. Molecular chemistry was assessed using a pyrolysis gas chromatograph (py-GC) equipped with a thermal desorption unit coupled to a time of flight mass spectrometer (MS) (py-GC/MS) and solid-state nuclear magnetic resonance $\left({ }^{13} \mathrm{C}\right.$ CP-MAS SS NMR). The pyrolysis products of the coal samples are generally similar, comprised of low and high molecular weight alkanes, alkylbenzenes, alkylphenols, and alkyl-subtituted polycyclic aromatic hydrocarbons, although the vitrinite-rich sample is chemically more diverse. The lack of diversity exhibited by the inertinite-rich sample upon pyrolysis may be interpreted to suggest that major components were heated in their geologic history. Based on the ${ }^{13} \mathrm{C} \mathrm{CP}-$ MAS SS NMR analysis, the inertinite-rich sample has a greater fraction of phenolics, reflected in the py-GC/MS results as substituted and unsubstituted derivatives. The greater abundance of phenolics for the inertinite-rich sample may suggest a fire-related origin for the dominant macerals of this sample. The $\mathrm{C}_{2}$-alkylbenzene isomers ( $p$-xylene and $o$-xylene) were detected in the pyrolysis products for the vitrinite-rich and inertinite-rich samples, though more abundant in the former. The presence of these in both samples likely reflects common source vegetation for the dominant vitrinite and inertinite macerals.
\end{abstract}

Keywords Py-TD-GC-TOFMS · Main Karoo Basin · Pyrolysis products $\cdot{ }^{13} \mathrm{C}$ CP-MAS SS NMR $\cdot$ Molecular chemistry Phenolics $\cdot$ Xylene $\left(\mathrm{C}_{2}\right.$-alkylbenzene) isomers

Ofentse M. Moroeng

marvinm@uj.ac.za

1 Department of Geology, University of Johannesburg, P.O. Box 524, Auckland Park 2006, South Africa

2 Department of Chemistry, College of Science Engineering and Technology, University of South Africa, P.O. Box 392, Pretoria 0003, South Africa

3 Department of Geology, University of Pretoria, Mineral Sciences Building, Pretoria 0002, South Africa

\section{Introduction}

The organic chemistry of coal is a complex product of the various progenitors for the individual macerals. During peatification, diagenesis, and subsequent coalification processes, the original vegetation is decomposed, altered, and ultimately transformed into coal. South African coals occurring in the Main Karoo Basin (MKB) are generally rich in inertinite with variable proportions of vitrinite, a relationship which may be considered to be the inverse of that observed in most Northern Hemisphere coals (Falcon 1986; O'Keefe et al. 2013). The formation of the inertiniterich, Karoo coals need to be understood in terms of the 
original material, and the origin pathways along which the inertinite and vitrinite macerals evolved.

Most vitrinite macerals are derived from the humification and gelification of woody tissues composed of lignin, cellulose, and a hemicellulose fraction (Teichmüller 1989; van Krevelen 1993; Hatcher and Clifford 1997; ICCP 1998; O'Keefe et al. 2013). In addition to the wood itself, other vitrinite macerals, such as corpogelinite and gelinite, are derived primarily from cell wall secretions and the contents thereof, or alternatively, from humic gels infilling cells, pores, and fissures (ICCP 1998; O'Keefe et al. 2013). The origin of inertinite macerals is variable for different macerals belonging to this group (van Krevelen 1993; ICCP 2001), derived through multiple origin pathways (Hower et al. 2011a, 2013; O'Keefe et al. 2013; Moroeng et al. 2018a, b, c). However, there is some general consensus that some macerals of this group, such as semifusinite and fusinite, formed through the charring of woody plant matter (Austen et al. 1966; Scott 1989, 2002, 2010; Diessel 1992, 2010; ICCP 2001; Glasspool 2003a, b; Hower et al. 2013; O'Keefe et al. 2013; Moroeng et al. $2018 \mathrm{a}, \mathrm{b}, \mathrm{c})$. Other authors contend that semifusinite may also form through the aerial oxidation of parechymatous and xylem tissues of plants (Falcon 1986; Falcon and Snyman 1986; Hagelskamp and Snyman 1988; Snyman 1989; Taylor et al. 1998; ICCP 2001). Other inertinite macerals form through the degradation of plant matter by organisms (macrinite), and from the remains of the organisms (funginite) (Moore et al. 1996; Moore and Shearer 1997; ICCP 2001; Hower et al. 2009, 2011b), or from the partially digested excretion and/or regurgitation products (so-called copromacrinite) of those organisms (Hower et al. 2011a, 2013; O'Keefe et al. 2013; Valentim et al. 2016). Inertodetrinite represents reworked plant matter that would have produced primary inertinite macerals, and secretinite reflects extreme oxidation or charring of resin and humic gels (ICCP 2001; O'Keefe et al. 2013).

The organic chemical composition of coal, with coal being a product of most kingdoms of life (Hower et al. 2009, 2011b), is thus informed by: (1) the various botanical and zoological precursor materials; (2) processes that altered the matter during peatification, diagenesis, and subsequent coalification processes; (3) the level of coal maturity; as well as, (4) the depositional environment in its entirety, what Hower et al. (2011b, p. 187) term the "total environment".

Various analytical techniques have been used in an attempt to elucidate the chemistry of the maceral components of coal. Although numerous studies discuss the pyrolysis-gas chromatography mass spectrometry results for various macerals, and especially vitrinite-rich coals of the Northern Hemisphere (e.g., Meuzelaar et al. 1984; Senftle et al. 1986; Senftle and Larter 1987, Nip et al.
1988, 1992; Eglinton et al. 1990, 1991; Boreham and Powell 1991; Powell et al. 1991; van Krevelen 1993, and references therein; Hartgers et al. 1994; Veld et al. 1994; Han et al. 1995; Odden and Barth 2000; Davidson 2004, and references therein; Sun and Horsfield 2005; Liu and Peng 2008; al Sandouk-Lincke et al. 2014; Zieger et al. 2018), studies using inertinite-dominated South African coals are comparatively sparse.

The main purpose of the present study is to examine differences and/or similarities in the organic molecular chemistry of iso-rank bituminous coals, a vitrinite-rich and an inertinite-rich sample, using a pyrolysis gas chromatograph (py-GC) equipped with a thermal desorption unit (TDU) coupled to a time of flight (TOF) mass spectrometer (MS) (py-GC/MS) in order to understand the effect of source vegetation and origin pathways on coal pyrolysis products. As liptinite normally accounts for a minor proportion of the coals of the MKB (Falcon and Snyman 1986; Kruszewska 2003; Van Niekerk et al. 2008), it is omitted from the present discussion. A medium rank $\mathrm{C}$ bituminous Witbank coal from the No. 4 Seam Upper was density-fractionated to create the required samples, enhancing compositional differences between the samples without introducing rank-dependent variations. Along with the widely used carbon-13 cross-polarization magic-anglespinning solid-state nuclear magnetic resonance analysis $\left({ }^{13} \mathrm{C}\right.$ CP-MAS SS NMR), py-GC/MS is used to investigate the organic molecular chemistry of the samples. The ${ }^{13} \mathrm{C}$ CP-MAS SS NMR results of these samples (including spectra) were reported by Moroeng et al. (2018a). However, aside from the aromatic cluster sizes, other ${ }^{13} \mathrm{C} \mathrm{CP}$ MAS SS NMR chemical-structural parameters were not explored by Moroeng et al. (2018a).

\section{Samples and analytical methods}

\subsection{Samples and preparation}

A run-of-mine coal sample (weighing approximately $50 \mathrm{~kg}$ ) was obtained from the No. 4 Seam Upper, Witbank Coalfield. Following crushing, a quarter of the original sample was reserved to represent the "parent" coal sample. The parent sample was density-fractionated at an RD of 1.3 and 1.8 to create the required vitrinite-rich and inertiniterich samples, respectively, following South African National Standard (SANS) 7936 (2010).

\subsection{Proximate, elemental, and petrographic analysis}

The proximate (moisture, ash, volatile matter, and fixed carbon) and elemental analyses $(\mathrm{C}, \mathrm{H}, \mathrm{N}, \mathrm{O}$, and $\mathrm{S}$ ) were undertaken at a commercial laboratory (Bureau Veritas, 
Centurion, South Africa) following prescribed SANS standards (SANS 334 1992; SANS 17247 2006; SANS 17246 2011).

The samples were prepared for petrographic analysis as polished blocks following SANS 7404-2 (2015). The maceral analysis was undertaken following SANS 7404-3 (2016) by means of a 500 point-count, using a Zeiss AxioImager $\mathrm{m} 2 \mathrm{M}$ reflected light microscope retrofitted with Hilgers Diskus Fossil components and software, at a total magnification of $500 \times$ using immersion oil. The mean random vitrinite reflectance $(\% \mathrm{RoVmr})$ of the coal was determined on the parent sample by a 100 point-count on collotelinite, following SANS 7404-5 (2016).

\subsection{Nuclear magnetic resonance analysis}

The ${ }^{13} \mathrm{C}$ CP-MAS SS NMR methodology is described extensively by Moroeng et al. (2018a), and will only be briefly described in the present study.

${ }^{13}$ C CP-MAS SS NMR coupled with dipolar dephasing (CP-MAS/DD) was used to compare the coal samples, following the method described by Solum et al. (1989). These two experiments were performed on each sample to determine the structural differences between the parent coal, vitrinite-rich, and inertinite-rich samples. The structural parameters were calculated based on Solum et al. (1989) and Suggate and Dickinson (2004). The spectra were acquired using an Agilent VNMRS $500 \mathrm{MHz}$ twochannel NMR spectrometer using $4 \mathrm{~mm}$ zirconia rotors and a $4 \mathrm{~mm}$ Chemagnetics TM T3 HXY MAS probe. All CP spectra were recorded with the latest VnmrJ 4.2 instrument software at ambient temperature with optimized highpower proton decoupling; a relaxation delay of $3 \mathrm{~s}$ and 10 000 scans were collected for obtaining sufficient signal-tonoise ratio. The power parameters were optimized for the Hartmann-Hahn match; the radio frequency fields were $\gamma \mathrm{CB} 1 \mathrm{C}=\gamma \mathrm{HB} 1 \mathrm{H} \approx 56 \mathrm{kHz}$. The contact time selected for $\mathrm{CP}$ was $2 \mathrm{~ms}$. The free induction decay recorded 2000 points and was Fourier transformed with a $125 \mathrm{~Hz}$ line broadening. Magic-angle-spinning (MAS) rate of $12 \mathrm{kHz}$ and Admantane was used as an external chemical shift standard with the upfield methyl peak-referenced to $38.4 \mathrm{ppm}$.

The DD experiments were carried out under the same CP parameters with the interrupted decoupling constant of the tancpxidref sequence set to $40 \mu \mathrm{s}$, after first evaluating an incremental array of $10-100 \mu$ s time constants.

Regarding spectra processing, the integration reset points were adapted from Solum et al. (1989) and Mestrenova 11.02 "preset integral regions table" was made to ensure that the exact same regions were integrated reproducibly. The individual spectra were each phased and baseline corrected manually before integration. All spectra were processed in the same manner and by the same person to minimize operator bias. The absolute integral values were transferred to a Microsoft Excel spreadsheet for calculation of the coal structural parameters as per Solum et al. (1989). No variable contact time was performed, as suggested by Solum et al. (1989), because of the long acquisition times. A contact time of $2 \mathrm{~ms}$ was used for all experiments and a correction factor of 1.3 , derived from Solum et al. (1989), was used to correct the intensity of the bridgehead aromatic carbons (peak 135-90 ppm for DD) for the loss of magnetization during the interrupted decoupling.

\subsection{Pyrolysis-gas chromatography mass spectrometry analysis}

The py-TD-GC-TOFMS system used in this study consisted of an Agilent 6890B (Agilent Technologies, USA) gas chromatograph and a Pegasus III TOF-MS (LECO, USA) equipped with a Gerstel autosampler, thermo desorption unit (TDU, Gerstel), pyrolysis module (Pyro, Gerstel) and cooled injection system (CIS, Gerstel) housed at the University of South Africa (Department of Chemistry, Florida, Johannesburg).

The samples were milled to a particle size of $-212 \mu \mathrm{m}$ for the py-GC/MS analysis. Samples $( \pm 3 \mathrm{mg})$ were placed in small quartz tubes and inserted into the pyrolysis unit. The samples were heated to $700{ }^{\circ} \mathrm{C}$ at a rate of $5{ }^{\circ} \mathrm{C} / \mathrm{s}$ and kept at that temperature for $1 \mathrm{~min}$. Thermal desorption was then carried out from 40 to $350{ }^{\circ} \mathrm{C}$ ( 3 min hold time) at $240{ }^{\circ} \mathrm{C} \mathrm{min}-1$. The desorbed volatiles were cryogenically focused using a Gerstel cooled injection system (CIS) at $-25{ }^{\circ} \mathrm{C}$ using liquid nitrogen. The analytes moved onto the GC column through the transfer line heated at $350{ }^{\circ} \mathrm{C}$ and then separated using a Restek Rxi-17Sil MS capillary column $(30 \mathrm{~m} \times 0.25 \mathrm{~mm} \times 0.25 \mu \mathrm{m})$ with helium as the carrier gas at a constant flow rate of $1.4 \mathrm{~mL} \mathrm{~min}^{-1}$ throughout the analysis. The initial oven temperature was $50{ }^{\circ} \mathrm{C}$ and held for $1 \mathrm{~min}$, then increased to $300{ }^{\circ} \mathrm{C}$ at a rate of $9{ }^{\circ} \mathrm{C} / \mathrm{min}$ and held constant for $2 \mathrm{~min}$. The injection port and transfer line temperatures were maintained at $300{ }^{\circ} \mathrm{C}$ and $310{ }^{\circ} \mathrm{C}$, respectively. The coal sample remained in the pyrolysis module during the entire GC run.

Mass acquisition was from 50 to 650 mass units at 10 spectra $\mathrm{s}^{-1}$ data acquisition rate. The electron energy was $70 \mathrm{eV}$ whilst mass spectrometer transfer line and ion source temperatures were $310{ }^{\circ} \mathrm{C}$ and $225^{\circ} \mathrm{C}$ respectively. Data acquisition and processing was carried out using ChromaTOF software version 4.0 (LECO, USA). Peak identification was made using library matching using the National Institute of Standards \& Technology (NIST) mass spectral library. Semi-quantitative data of the compounds was obtained by using the peak area for the compound as a 
percentage of the total area for all compounds detected. For each sample, analysis was done in triplicate and average results presented.

\section{Results and discussion}

\subsection{Proximate, elemental, and petrographic composition}

The proximate, elemental, and petrographic data are presented in Table 1. Based on the proximate analysis, the parent coal, vitrinite-rich, and inertinite-rich samples have similar moisture contents. The vitrinite-rich sample has the highest volatile matter content as well as the lowest ash content. The higher volatile content for the vitrinite-rich sample relative to the inertinite-rich counterpart is in agreement with published literature for bituminous coals (van Krevelen 1993; Van Niekerk et al. 2008, and references therein). The $\mathrm{H} / \mathrm{C}$ atomic ratio, which is indicative of aromatic fraction, is also in agreement with published literature regarding the greater aromatic fraction of bituminous inertinite-rich coals relative to vitrinite-rich counterparts at similar rank (Davidson 2004; Van Niekerk et al. 2008). The parent sample has the highest total sulphur content, which is significantly reduced in the densityfractionated samples, including the inertinite-rich sample despite the higher ash content. This suggests that the major form of sulphur in the parent coal is present as sulphide minerals (or other sulphur-bearing mineral phases), which reported to the 1.8 sink fraction, with organic sulphur comprising a minor proportion. The total nitrogen content of the samples is comparable, though the vitrinite-sample has the slightly higher proportion of this chemical element.

In terms of maceral group composition, the parent coal sample consists of $44.3 \mathrm{vol} \%$ vitrinite and $51.7 \mathrm{vol} \%$ inertinite (mineral-matter-free basis). This maceral composition is relatively enriched in vitrinite in comparison to most Witbank coals (e.g., Falcon and Snyman 1986; Roberts et al. 2015), although comparable to a sample used by Okolo et al. (2015). The $0.65 \%$ RoVmr $(\mathrm{SD}=0.067)$ indicates that the coal is medium rank $\mathrm{C}$ bituminous. As a result, the maceral nomenclature used follows that of the International Committee for Coal and Organic Petrology for bituminous rank coals (ICCP 1998, 2001; Pickel et al. 2017).

The semifusinite and inertodetrinite macerals were further subdivided into reactive and inert sub-macerals, as is the convention for South African coals (Falcon and Snyman 1986; Hagelskamp and Snyman 1988; Snyman 1989; Okolo et al. 2015).

The inertinite-rich sample comprises of 65.7 vol\% total inertinite macerals, where fusinite $(8.7 \mathrm{vol} \%)$, semifusinite
Table 1 Proximate, elemental (air dried), and maceral composition $(\mathrm{mmf}=$ mineral-matter-free basis $)$ results for the parent coal, inertinite-rich and vitrinite-rich samples

\begin{tabular}{|c|c|c|c|}
\hline Items & Parent & Inertinite-rich & Vitrinite-rich \\
\hline \multicolumn{4}{|l|}{ Proximate analysis (wt\%) } \\
\hline Moisture & 3.1 & 3.0 & 3.1 \\
\hline Ash & 12.5 & 13.4 & 4.2 \\
\hline Volatile matter & 30.7 & 28.5 & 38.6 \\
\hline Fixed carbon & 53.7 & 55.1 & 54.1 \\
\hline \multicolumn{4}{|l|}{ Elemental analysis (wt\%) } \\
\hline Carbon & 67.40 & 67.60 & 75.00 \\
\hline Hydrogen & 4.40 & 4.17 & 5.33 \\
\hline Nitrogen & 1.80 & 1.68 & 2.07 \\
\hline Oxygen & 8.61 & 9.57 & 9.58 \\
\hline Sulphur & 2.24 & 0.64 & 0.76 \\
\hline $\mathrm{H} / \mathrm{C}$ atomic ratio & 0.78 & 0.74 & 0.85 \\
\hline \multicolumn{4}{|c|}{ Maceral composition (vol\%) mmf } \\
\hline Telinite & 0.2 & 0.0 & 2.5 \\
\hline Collotelinite & 12.8 & 13.0 & 36.1 \\
\hline Vitrodetrinite & 0.0 & 0.0 & 0.0 \\
\hline Collodetrinite & 29.9 & 16.2 & 37.1 \\
\hline Corpogelinite & 1.5 & 0.5 & 7.1 \\
\hline Gelinite & 0.0 & 1.4 & 0.0 \\
\hline Pseudovitrinite & 0.0 & 0.2 & 0.4 \\
\hline Total vitrinite & 44.3 & 31.3 & 83.1 \\
\hline Fusinite & 9.2 & 8.7 & 4.0 \\
\hline Reactive semifusinite & 1.5 & 7.5 & 0.2 \\
\hline Inert semifusinite & 18.0 & 22.9 & 4.6 \\
\hline Micrinite & 0.4 & 0.2 & 0.0 \\
\hline Macrinite & 0.2 & 0.2 & 0.4 \\
\hline Secretinite & 1.3 & 1.3 & 0.6 \\
\hline Funginite & 0.0 & 0.0 & 0.0 \\
\hline Reactive inertodetrinite & 0.9 & 2.2 & 0.8 \\
\hline Inert inertodetrinite & 20.3 & 22.8 & 1.0 \\
\hline Total inertinite & 51.7 & 65.7 & 11.7 \\
\hline Sporinite & 3.5 & 3.0 & 3.0 \\
\hline Cutinite & 0.4 & 0.0 & 2.0 \\
\hline Resinite & 0.0 & 0.0 & 0.2 \\
\hline Alginite & 0.0 & 0.0 & 0.0 \\
\hline Liptodetrinite & 0.0 & 0.0 & 0.0 \\
\hline Exsudatinite & 0.0 & 0.0 & 0.0 \\
\hline Total liptinite & 3.9 & 3.0 & 5.2 \\
\hline$\%$ RoVmr & 0.65 & & \\
\hline $\begin{array}{l}\text { Standard Deviation } \\
\text { (SD) }\end{array}$ & 0.067 & & \\
\hline
\end{tabular}

$\% \mathrm{RoVmr}=$ mean random vitrinite reflectance

(reactive $=7.5 \mathrm{vol} \%$ and inert $=22.9 \mathrm{vol} \%)$ and inertodetrinite $($ reactive $=2.2 \mathrm{vol} \%$ and inert $=22.8 \mathrm{vol} \%$ ) are the principal inertinite macerals. In contrast, the vitriniterich counterpart is dominated by the vitrinite macerals 
(81.3 vol\% total vitrinite), collotelinite and collodetrinite, with lower proportions of telinite and corpogelinite. Because the dominant macerals of the density-fractionated samples were derived from similar plant organs, i.e. wood (ICCP 1998, 2001; Hower et al. 2013; O'Keefe et al. 2013), the pyrolysis products of the samples may be expected to either be similar or different. This would depend on which is the overriding parameter between source vegetation and origin pathways determining the pyrolysis products of the coal samples.

\subsection{Comparison of organic geochemistry of the vitrinite-rich and inertinite-rich samples}

Along with py-GC/MS, ${ }^{13} \mathrm{C} \mathrm{CP-MAS} \mathrm{SS} \mathrm{NMR} \mathrm{was} \mathrm{used} \mathrm{to}$ compare the molecular chemistry of the coal samples. Moroeng et al. (2018a) concluded that the ${ }^{13} \mathrm{C}$ CP-MAS SS NMR results are generally comparable with results obtained by others using advanced, direct polarization SS ${ }^{13} \mathrm{C}$ NMR coupled with spectral-editing techniques, for example the results reported by Cao et al. (2011, 2013). The results of the ${ }^{13} \mathrm{C}$ CP-MAS SS NMR analysis are given in Table 2. The greater aromatic fraction of inertinite-rich coals relative to vitrinite-rich counterparts at the bituminous rank is well-established (van Krevelen 1993; Davidson 2004; Van Niekerk et al. 2008), and the results of the present study largely concur with this (Table 2). Further, the results indicate that the inertinite-rich sample has the marginally greater fraction of phenolics $\left(f_{a}^{P}=0.13\right.$ vs. 0.09 for the vitrinite-rich sample). Although this sample has the greater overall aromatic fraction, the degree of alkyl substitution is greater for the aromatics of the vitrinite-rich sample. Despite lower overall aliphatic fraction $\left(f_{a l}\right)$, the inertinite-rich sample has a significantly higher proportion of aliphatic carbons bonded to oxygen $\left(f_{a l}^{o}=0.05\right.$ vs. 0.002 for the vitrinite-rich counterpart), along with a higher fraction of carbonyl/carboxyls $\left(f_{a}^{C O}\right)$. The proportion of non-protonated carbons and methyl groups in aliphatic compounds is larger for the vitrinite-rich sample $\left(f_{a}^{N^{*} \text { - }}\right.$ $=0.1$ ) relative to the other samples. The number of attachments per cluster $(\sigma+1)$ is larger for the inertiniterich sample in comparison to the vitrinite-rich counterpart. Therefore, the ${ }^{13} \mathrm{C}$ CP-MAS SS NMR chemical-structural parameters for the density-fractionated samples are markedly different, reflecting the greater aromatic fraction and oxygen-bearing functionalities for the inertinite-rich sample as well as the greater degree of alkyl substitution of aromatics for the vitrinite-rich sample. Moreover, aside from the average aromatic cluster size $(C)$ for the inertinite-rich sample, the ${ }^{13} \mathrm{C}$ CP-MAS SS NMR results are generally comparable with results obtained by others when evaluating the chemical-structural parameters for vitriniterich and inertinite-rich South African bituminous coals
Table 2 Chemical structural parameters from solid-state ${ }^{13} \mathrm{C} \mathrm{CP}$ NMR for the parent coal, inertinite-rich, and vitrinite-rich samples (Moroeng et al. 2018a)

\begin{tabular}{lclc}
\hline Items & Parent & Inertinite-rich & Vitrinite-rich \\
\hline$f_{a}$ & 0.73 & 0.72 & 0.68 \\
$f_{a}^{*}$ & 0.64 & 0.52 & 0.65 \\
$f_{a l}$ & 0.27 & 0.28 & 0.32 \\
$f_{a l}^{o}$ & 0.084 & 0.05 & 0.002 \\
$f_{a}^{C O}$ & 0.09 & 0.19 & 0.04 \\
$f_{a}^{P}$ & 0.09 & 0.13 & 0.09 \\
$f_{a}^{\mathrm{S}}$ & 0.13 & 0.11 & 0.17 \\
$f_{a}^{N}$ & 0.39 & 0.25 & 0.48 \\
$f_{a}^{H}$ & 0.25 & 0.28 & 0.17 \\
$f_{a}^{B}$ & 0.17 & 0.01 & 0.22 \\
$f_{a}^{N *}$ & 0.05 & 0.04 & 0.10 \\
$f_{a l}^{H}$ & 0.22 & 0.24 & 0.22 \\
$\mathrm{X}_{\mathrm{b}}$ & 0.26 & 0.02 & 0.34 \\
$\mathrm{C}$ & 13.9 & 5.80 & 17.3 \\
$\#$ Cluster/100 & 4.58 & 9.10 & 3.74 \\
$\sigma+1$ & 4.77 & 2.59 & 6.87
\end{tabular}

Parameters: $f_{a}$-Fraction aromatics, $f_{a}^{*}$-corrected fraction aromatics (excl. CO), $f_{a l}$-fraction aliphatics, $f_{a l}^{o}$-fraction aliphatic C's bonded to oxygen, $f_{a}^{C O}$-fraction $\mathrm{CO}, f_{a}^{P}$-fraction phenolics, $f_{a}^{S}$-fraction alkylated aromatics, $f_{a}^{N}$-fraction non-protonated C's in aromatic region, $f_{a}^{H}$-fraction Protonated C's in aromatic region, $f_{a}^{B}$-fraction bridgehead C's, $f_{a}^{N^{*}}$ - fraction non-protonated C's + methyl groups in aliphatics, $f_{a l}^{H}$-aliphatic $\mathrm{CH}+\mathrm{CH} 2, \mathrm{X}_{\mathrm{b}}-$ mole fraction of aromatic bridgehead C's, C-average \# of aromatic C's per cluster, \#Cluster/ 100 -average \# of clusters per 100 aromatic C's, $\boldsymbol{\sigma}+1-\#$ of attachment per cluster

(e.g., Van Niekerk et al. 2008; Okolo et al. 2015; Roberts et al. 2015).

The pyrolysis chromatograms for the parent, inertiniterich, and vitrinite-rich coal samples are presented, respectively, in Figs. 1, 2 and 3. Of the compounds detected during the py-GC/MS analysis, chemical compounds with an abundance (area \%) greater than $1 \%$ are given in Table 3. These compounds represent $75 \%, 78 \%$ and $71 \%$ of the pyrolysis products detected for the parent, inertiniterich, and vitrinite- rich samples, respectively. The chemical compounds presented were identified with a similarity of more than $70 \%$, and were arranged in order of increasing retention time in Table 3 to aid with peak identification on the chromatographs. For relatively simple compounds common in the pyrolysis products for the three samples such as phenol, benzene, xylene isomers, and fluorene, the py-GC/MS retention times are greatly comparable (Table 3). Differences appear to become more prominent for larger and/or more substituted compounds, thus with higher retention times. 


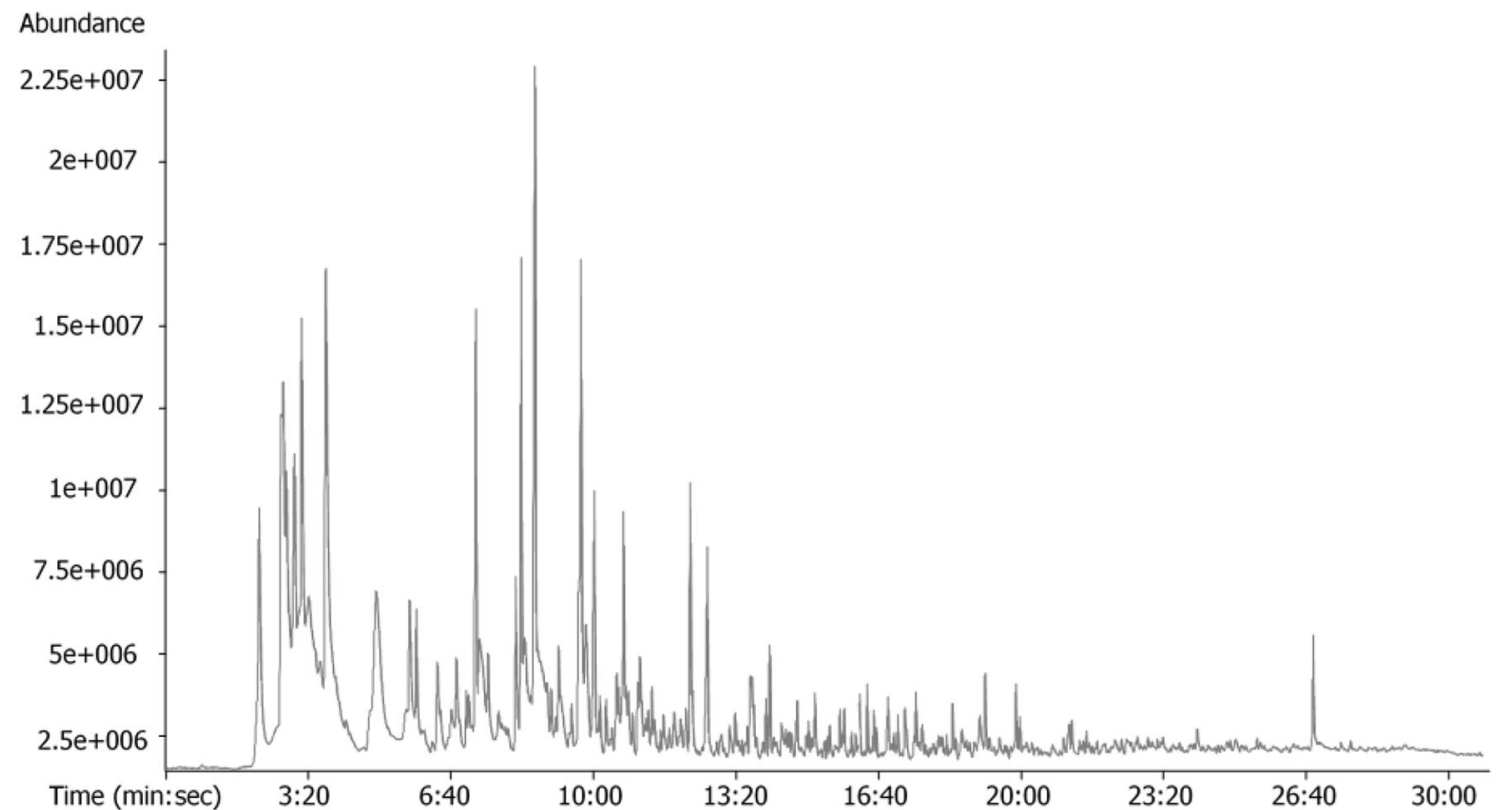

Fig. 1 Total ion chromatogram for the parent coal sample

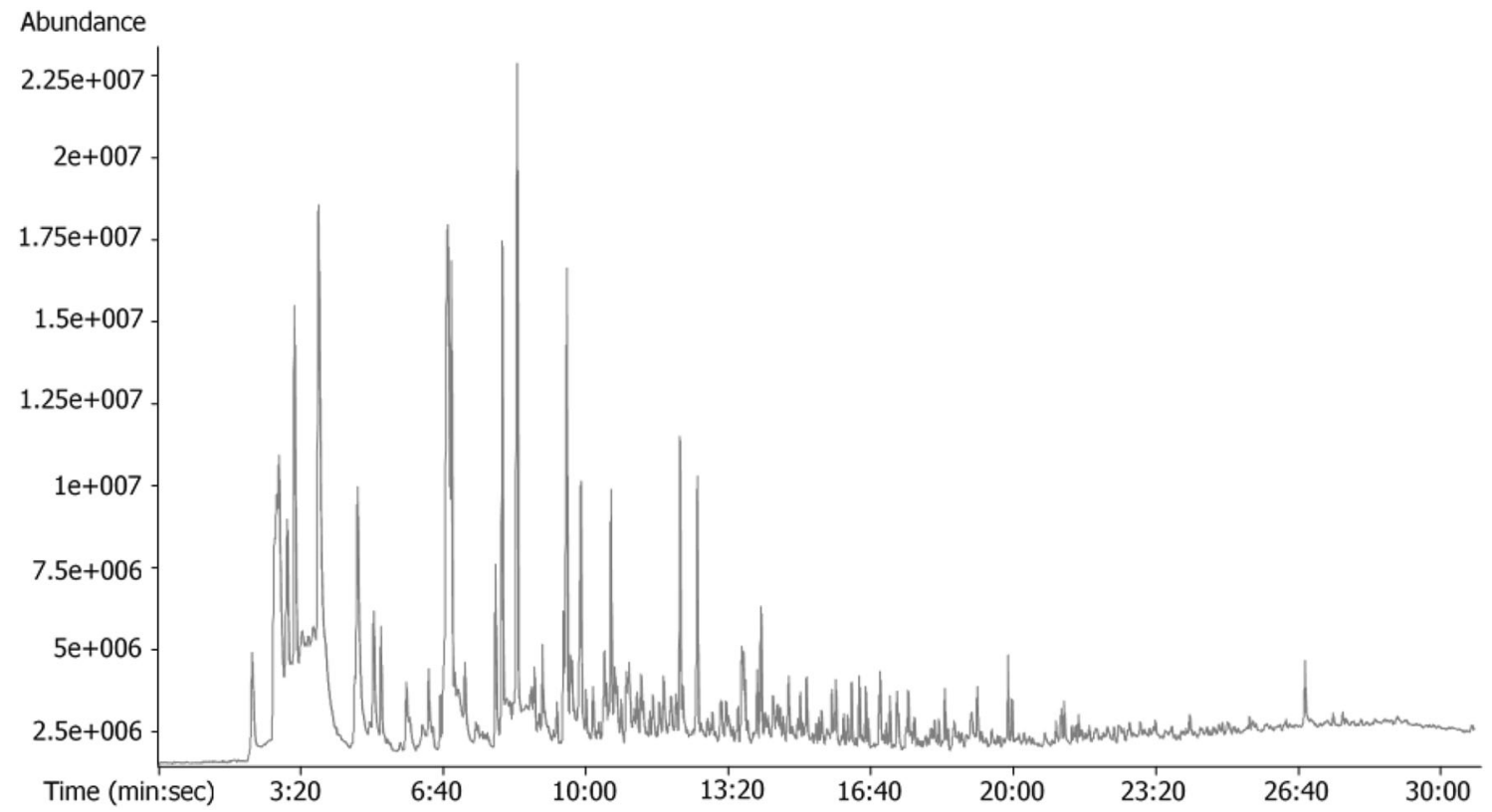

Fig. 2 Total ion chromatogram for the inertinite-rich sample

The pyrolysis products of the coal samples of the present study generally comprise of similar compounds reported for various coals from around the world (Table 3) (Meuzelaar et al. 1984; Senftle and Larter 1987; Eglinton et al. 1991; Powell et al. 1991; Nip et al. 1988, 1992; van Krevelen 1993, and references therein; Hartgers et al. 1994; Veld et al. 1994; Zieger et al. 2018), and South Africa (Van Niekerk et al. 2008). The aliphatic fraction of the pyrolysis products is comprised of a range of low molecular weight (carbon number, $\mathrm{C}_{4}$ ) to relatively high molecular weight $\left(\mathrm{C}_{30}\right)$ cyclic and branched alkanes and alkenes. With the aid of flash-pyrolysis GCMS, Van Niekerk et al. (2008) reported long-chain alkane and alkene compounds ranging up to $\mathrm{C}_{23}$ for vitrinite-rich Waterberg and inertinite-rich Highveld bituminous coals. Further, the pyrolysis products of the vitrinite-rich Waterberg sample were reported to comprise of a greater proportion of aliphatic compounds relative to the inertinite-rich sample 


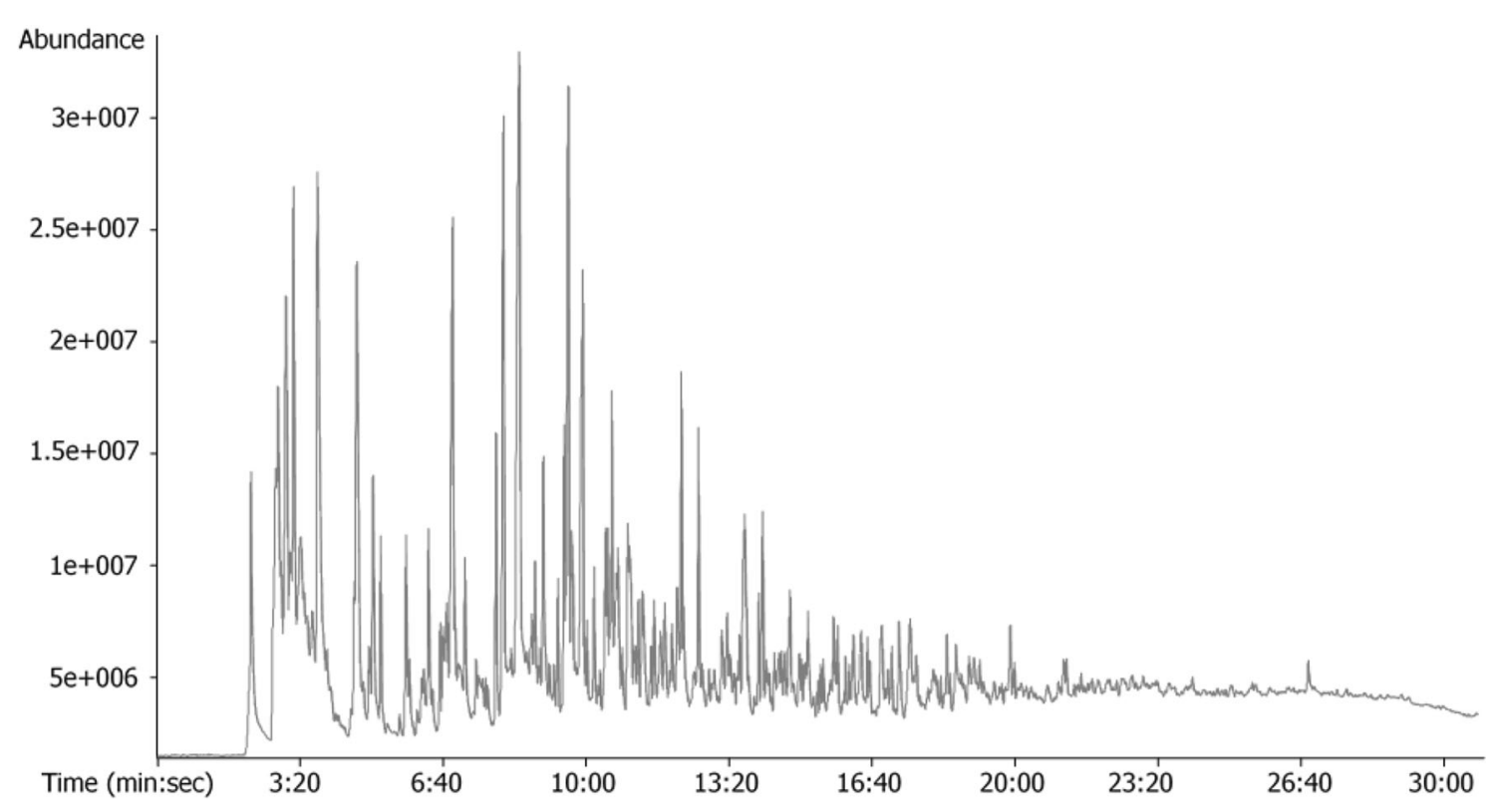

Fig. 3 Total ion chromatogram for the vitrinite-rich sample

(Van Niekerk et al. 2008), consistent with the ${ }^{13}$ C CP-MAS SS NMR results of this study (Table 2).

The aromatic fraction of the pyrolysis products for the samples of the present study comprise of a significant amount of substituted and unsubstituted 6-aromatic carbon ring functional groups. For the inertinite-rich sample, the abundance of these monocyclic rings is confirmed by the ${ }^{13} \mathrm{C}$ CP-MAS SS NMR results (Table 2), specifically the average number of aromatic carbons per cluster (C). The most abundant polycyclic aromatic hydrocarbons (PAHs) detected in the pyrolysis products are naphthalene and flourene, similar to the results obtained by Zieger et al. (2018) for vitrinites of Carboniferous Age from the Ruhr Basin, Northwest Germany. Other larger PAHs such as pyrene, anthracene, and phenanthrene are present in minor amounts, hence they were excluded from Table 3. The PAHs mostly occur as alkyl-substituted derivatives, consistent with other studies (e.g., Van Niekerk et al. 2008; Zieger et al. 2018).

Ethane-tribromo- and trichloromethane (halogenated hydrocarbons) were also detected during the analysis. Of these, the latter is common to all the samples, whereas the former only present in the pyrolysis products of the inertinite-rich sample. Despite the fact that the parent coal and the inertinite-rich sample have comparable ash contents, the inertinite-rich sample has a lower total sulphur content. This may be interpreted to suggest that the organic sulphur content of the coals is lower, assuming that the sulphides reported in the 1.8 sink fraction, as previously suggested. This is also supported by the minor sulphur-bearing organic compounds (e.g., 3, 4-Epoxytetrahydrothiophene-1, 1-dioxide for the parent coal) detected during the py-GC/
MS analysis. Likewise, nitrogen-bearing compounds (e.g., 1H-Pyrrole, 2-methyl-) were detected with a low abundance. However, it should be mentioned that Phiri et al. (2018) observed the dependence of pyrrolic nitrogen on pyrolysis temperature.

Through visual inspection, it becomes evident that the pyrolysis chromatogram for the parent coal (Fig. 1) is more comparable to that of the inertinite-rich sample (Fig. 2), likely reflecting similarities in petrographic composition (Table 1). The chromatograph for vitrinite-rich sample (Fig. 3) is markedly different, exhibiting greater chemical diversity in comparison to the other samples, possibly resulting from the greater aliphatic fraction and alkyl substitution as reflected in the ${ }^{13} \mathrm{C}$ CP-MAS SS NMR results (Table 2).

Van Niekerk et al. (2008) also observed marked differences in the molecular chemistry for vitrinite-rich Waterberg and inertinite-rich Highveld coal samples, with greater variability observed for the former sample, thus in agreement with the finding of the present study. Further, most compounds detected during the py-GC/MS analysis (Fig. 3) appear to be generally more abundant in the vitrinite-rich sample. Because the coals used by Van Niekerk et al. (2008) were obtained from two different coalfields, an argument could be made that differences between vitriniterich Waterberg and inertinite-rich Highveld also reflect differences in source vegetation and/or depositional environments. However, the results of the present study may be taken to contradict such an interpretation, instead suggesting inherent differences in the pyrolysis products for the vitrinite and inertinite macerals. 


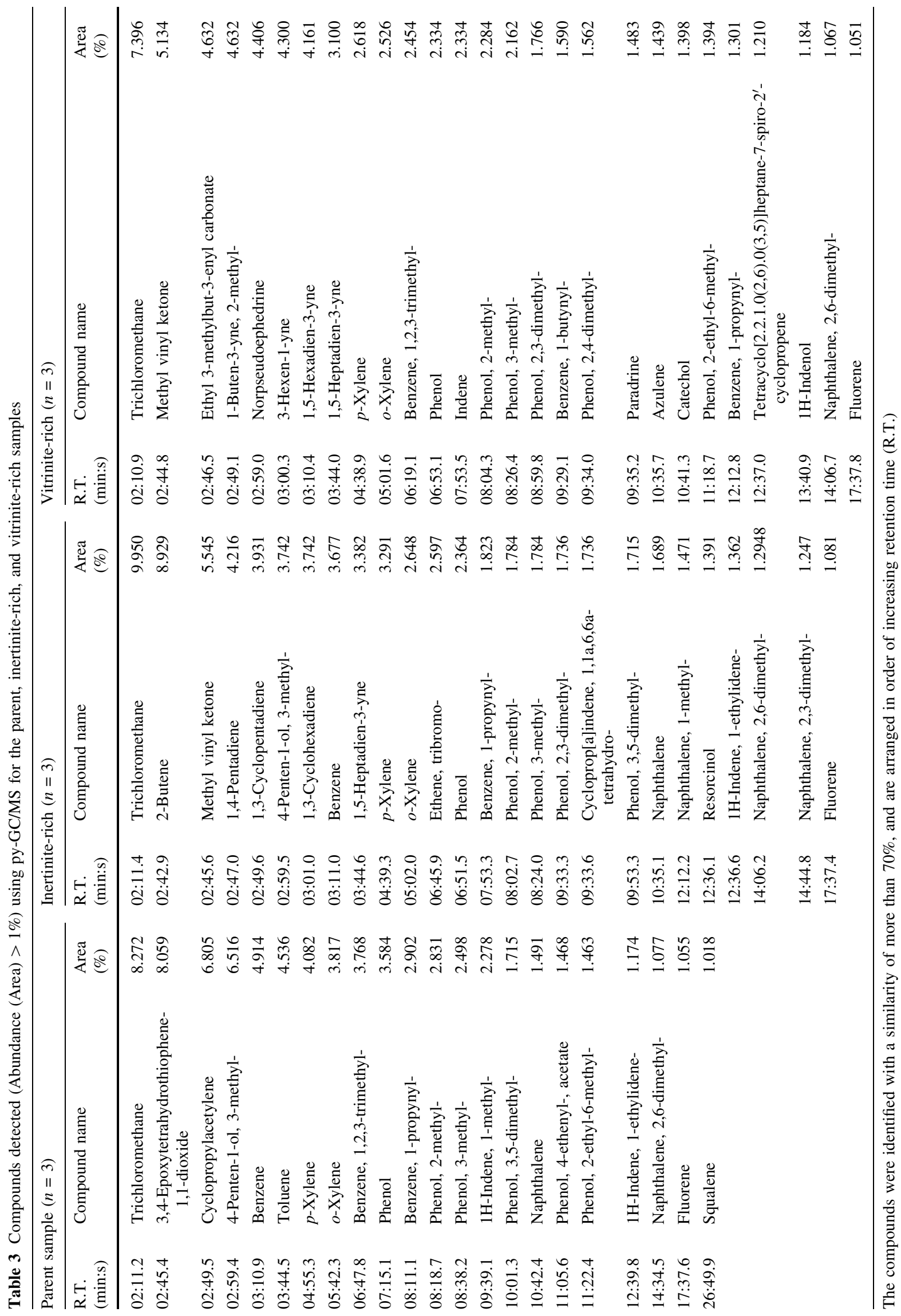


The varied pyrolysis products for the vitrinite-rich sample, as reflected in Fig. 3, is interpreted to suggest that humification and gelification processes result in the formation of chemical compounds able to give off diverse products upon pyrolysis. Similarly, the lack of diversity for inertinite-rich sample (Fig. 2) reflects the origin pathway for the dominant inertinite macerals. Moroeng et al. (2018a, b, c) proposed that the dominant inertinite macerals of the coal samples of the present study were formed through charring of plant matter. Accepting charring as an origin pathway for these macerals, this process would likely have resulted in the volatilization of certain chemical species, which were driven off, and are currently reflected by the lack of chemical diversity in the chromatogram for the inertinite-rich sample (Fig. 2). The inertinite macerals may essentially be interpreted to have been pre-pyrolyzed in their geologic history as a result of the origin pathway, prior to the py-GC/MS analysis. Further, the lack of chemical diversity for the pyrolysis products of the inertinite-rich sample may also be interpreted to suggest the dominant inertinite macerals, fusinite, semifusinite, and inertodetrinite, have similar origin pathways and source vegetation, especially considering that this sample also has a significant proportion of vitrinite $(31.3 \mathrm{vol} \%$-mineralmatter free). The lack of diversity may, therefore, be taken to be consistent with the view that inertodetrinite represents fusinitized and semifusinitized plant matter that was subsequently fragmented (Hagelskamp and Snyman 1988; ICCP 2001; O'Keefe et al. 2013).

Various other workers have argued for a fire-origin for certain inertinite macerals, such as fusinite and semifusinite (Austen et al. 1966; Scott 1989, 2002, 2010; Diessel 1992, 2010; ICCP 2001; Glasspool 2003a, b; Hower et al. 2013; Jasper et al. 2013; O'Keefe et al. 2013; Moroeng et al. 2018a, b, c). Along with inertodetrinite, these are the abundant inertinite macerals in the Witbank coals of this study. The greater proportion of phenolics for the inertinite-rich sample (Table 2) may also be consistent with a fire-origin for the major inertinite macerals of this sample, as concluded by Moroeng et al. (2018a). This is based on the fact that pyrolysis experiments using ligninrich wood at temperatures below $400{ }^{\circ} \mathrm{C}$ produces phenolic moieties (Asmadi et al. 2011; Kawamoto 2017). However, the phenolic moieties produced during the pyrolysis experiments are methoxy-substituted. The absence of methoxy-substituted phenols in the pyrolysis products of the inertinite-rich sample, in particular, may suggest that the methoxy functionalities were expelled during the course of coalification (Austen et al. 1966; Senftle and Larter 1987; Nip et al. 1988; van Krevelen 1993, and references therein). It should be noted that methoxy-substituted phenols have been observed in low rank coals
(Senftle and Larter 1987, and references therein; van Krevelen 1993, and references therein).

Despite the diversity exhibited by the vitrinite-rich sample, the pyrolysis products identified for three samples of this study are generally similar (Table 2). The abundance of the compounds identified appear to vary between the samples (Figs. 1, 2, 3), possibly depending on the dominant macerals of the each coal sample. This observation is consistent with the findings of Nip et al. (1992) for single maceral fractions (cutinite, resinite, sporinite, vitrinite, pseudovitrinite, semifusinite, and fusinite) of Carboniferous Age from the Brazil Block seam (Roaring Creek Mine, Parke County) prepared using density gradient centrifugation. For the present study, phenolic compounds are a prominent example of a functional group reflected in the py-GC/MS and ${ }^{13} \mathrm{C}$ CP-MAS SS NMR results. According to Powell et al. (1991), phenolics are abundant in the pyrolysis products of low-rank coals as opposed to higher rank counterparts. Similar observations were made by Senftle et al. (1986) using vitrinite concentrates from the Lower Kittanning Seam (Pennsylvania), ranging in maturity from medium rank D to $\mathrm{A}$. The fraction of phenolics for all three coal samples of this study comprises of a range unsubstituted and substituted (e.g., Phenol, 3, 5-dimethyl-; Phenol, 2-ethyl-6-methyl-) derivatives.

Nip et al. (1988) found that $p$-xylene and $m$-xylene were the major $\mathrm{C}_{2}$-alkylbenzenes in the pyrolysis products of vitrinite and inertinite macerals from the Lower and Middle Yorkshire Coalfield (UK), whereas $o$-xylene was observed to be a major product of liptinite pyrolysis. This finding contrasts somewhat with the results of the present study. In the first instance, $m$-xylene was not detected in the pyrolysis products of the Witbank coal samples. Secondly, $p$ xylene and $o$-xylene were detected in the pyrolysis products for the parent, vitrinite-rich, and inertinite-rich samples, though in varying proportions. For the three samples, $p$-xylene was consistently observed to be more abundant than $o$-xylene.

Given that the inertinite-rich and vitrinite-rich samples are products of the same coal, differences in the proportions of the xylene isomers present in the pyrolysis products reflect differences between the major maceral groups, and not rank-dependent differences (Nip et al. 1988). This may be taken to suggest that for Witbank coals, $p$-xylene and $o$-xylene are the major pyrolysis products for vitrinite macerals in particular. Alternatively, if the xylene isomers are pyrolysis products for the dominant inertinite macerals as well, this would have to be interpreted to suggest that origin pathways for the vitrinite and inertinite macerals produce chemical species that are able to give off the xylene isomers during pyrolysis. Although forming through different pathways, the dominant inertinite and vitrinite macerals of the samples are derived primarily from the 
woody tissues of plants, and the xylene isomers are thought to be derived from the lignin component of the wood (Nip et al. 1988). As a result, the presence of xylene isomers in the pyrolysis products for the vitrinite-rich and inertiniterich samples may suggest that these reflect the comparable source vegetation as opposed to the different origin pathways (Senftle and Larter 1987).

Assuming that the xylene isomers reflect source vegetation for macerals present in these Witbank coals, the detection of largely similar pyrolysis products for both the vitrinite-rich and inertinite-rich samples may be interpreted to suggest a continuum in chemical composition between the dominant vitrinite and inertinite macerals (Nip et al. 1992). Because collotelinite, collodetrinite, fusinite, and semifusinite have similar botanical precursors, similarities in the pyrolysis products of these macerals may be expected, as suggested by Powell et al. (1991). For South African coals, this has been established based chiefly on petrographic observations. As an example, the semifusinite component of South African coals is typically subdivided into a reactive and an inert sub-maceral (Falcon and Snyman 1986; Hagelskamp and Snyman 1988; Snyman 1989; Okolo et al. 2015). The subdivision accounts for reactive semifusinite possessing petrographic and chemical properties more comparable to vitrinite, whereas the inert counterpart possesses properties similar to fusinite of the same coal sample.

According to Nip et al. (1992), pyrolysis products can be used as a "fingerprint" to discriminate between different macerals. In this regard, the findings of the present study may be considered somewhat inconclusive and thus warrant further investigation, specifically with the use of advanced maceral separation techniques. This derives from the differences observed in the chromatograms for inertinite-rich and vitrinite-rich samples, suggesting differences in molecular composition which may be obscured by the relative impurity of the coal samples. With purer maceral fractions, it may be possible to assign pyrolysis products to specific macerals with a higher degree of confidence. However, it should be mentioned that even for largely pure maceral fractions prepared using density-gradient centrifugation from the Argonne Premium Coal Sample Program (for example, fractions comprised of $96.5 \mathrm{vol} \%$ liptinite, $100 \mathrm{vol} \%$ vitrinite, and 99 vol\% inertinite, respectively), Hartgers et al. (1994) encountered difficulties with assigning pyrolysis products to specific macerals, instead suggesting assignment on the basis of an assemblage of functional groups detected.

\section{Conclusion}

The study evaluated the organic geochemistry of a vitrinite-rich and an inertinite-rich sample derived from a medium rank $\mathrm{C}$ bituminous coal (derived from the same coal, i.e., iso-rank) from the No. 4 Seam Upper of the Witbank Coalfield (South Africa) using pyrolysis py-GC/ MS and ${ }^{13} \mathrm{C}$ CP-MAS SS NMR. The vitrinite-rich sample (81.3 vol\% vitrinite, mineral-matter-free basis) had an abundance of collotelinite and collodetrinite. In contrast, the inertinite-rich counterpart ( 65.7 vol\% inertinite) was dominated by fusinite, and variable proportions of both the reactive and inert semifusinite and inertodetrinite submacerals. Pyrolysis products for the vitrinite-rich and inertinite-rich samples generally comprised of similar organic molecules, although the former sample was more diverse and had a greater abundance of most compounds. The lack of diversity for the inertinite-rich sample was interpreted to suggest that the dominant macerals were prepyrolyzed in their geologic history, thus supporting a fireorigin for the specific macerals. According to the ${ }^{13} \mathrm{C} \mathrm{CP}$ MAS SS NMR analysis, the inertinite-rich sample had a higher fraction of phenolics, which comprised of a range of substituted and unsubstituted functionalities along with polycyclic aromatic compounds (PAHs) reflected in the pyGC/MS results. The abundance of phenolics for the inertinite-rich sample was also interpreted to be consistent with a fire-origin for the dominant inertinite macerals. The $\mathrm{C}_{2^{-}}$ alkylbenzene isomer, $p$-xylene, was observed to be more abundant in the samples than $o$-xylene, whereas $m$-xylene was not detected. The xylene isomers are likely derived from the lignin component of woody plant matter, the precursor for the dominant vitrinite and inertinite macerals of the coal samples, thus suggesting that the isomers reflect source vegetation. The relative petrographic impurity of the samples rendered the assignment of the compounds to specific macerals difficult.

Acknowledgements Dr. H. Dorland (CIMERA, UJ) is thanked for assistance with obtaining the sample used in the study. The lead author acknowledges the Research, Education and Investment (REI) Fund of the Geological Society of South Africa (GSSA), National Research Foundation of South Africa (NRF), and the University of Johannesburg's (UJ) Centre of Excellence for Integrated Mineral and Energy Resource Analysis (CIMERA) for funding. The authors acknowledge that the opinions, findings and conclusions or recommendations expressed in this publication are those of the authors and that the NRF accepts no liability whatsoever in this regard. This study is part of a PhD thesis prepared by OMM. The authors wish to thank Dr. S. Peng for editorial handling. Two anonymous reviewers are also gratefully acknowledged for their valuable input, which helped improve the manuscript. 


\section{Compliance with ethical standards}

Conflict of interests The authors declare that they have no competing interests.

Open Access This article is distributed under the terms of the Creative Commons Attribution 4.0 International License (http://crea tivecommons.org/licenses/by/4.0/), which permits unrestricted use, distribution, and reproduction in any medium, provided you give appropriate credit to the original author(s) and the source, provide a link to the Creative Commons license, and indicate if changes were made.

\section{References}

al Sandouk-Lincke NA, Schwarzbauer J, Hartkopf-Fröder C, Volk H, Fuentes D, Young M, Littke R (2014) The effect of different pyrolysis temperatures on organic microfossils, vitrain and amber-a comparative study between laser assisted- and Curie point-pyrolysis-gas chromatography/mass spectrometry. J Anal Appl Pyrol 107:211-223

Asmadi M, Kawamoto H, Saka S (2011) Thermal reactions of guaiacol and syringol as lignin model aromatic nuclei. J Anal Appl Pyrol 92:88-98

Austen DEG, Ingram DJE, Given PH, Binder CR, Hill LW (1966) Electron spin resonance study of pure macerals. In: Given PH (ed) Coal science, advances in chemistry, vol 55. American Chemical Society, Washington, DC, pp 344-362

Boreham CJ, Powell TG (1991) Variation in pyrolysate composition of sediments from the Jurassic Walloon Coal Measures, eastern Australia as a function of thermal maturation. Org Geochem 17(6):723-733

Cao X, Mastalerz M, Chappell MA, Miller LF, Li Y, Mao J (2011) Chemical structures of coal lithotypes before and after $\mathrm{CO}_{2}$ adsorption as investigated by advanced solid-state ${ }^{13} \mathrm{C}$ nuclear magnetic resonance spectroscopy. Int $\mathrm{J}$ Coal Geol 88(1):67-74

Cao X, Chappell MA, Schimmelmann A, Mastalerz M, Li Y, Hu W, Mao J (2013) Chemical structure changes in kerogen from bituminous coal in response to dike intrusions as investigated by advanced solid-state ${ }^{13} \mathrm{C}$ NMR spectroscopy. Int J Coal Geol 108:53-64

Davidson RM (2004) Studying the structural chemistry of coal. IEA Clean Coal Centre, London

Diessel CFK (1992) Coal-bearing depositional systems. Springer, Berlin

Diessel CFK (2010) The stratigraphic distribution of inertinite. Int J Coal Geol 81(4):251-268

Eglinton TI, Sinninghe Damsté JS, Kohnen MEL, de Leeuw JW (1990) Rapid estimation of the organic sulphur content of kerogens, coals and asphaltenes by pyrolysis-gas chromatography. Fuel 69:1394-1404

Eglinton TI, Larter SR, Boon JJ (1991) Characterisation of kerogens, coals and asphaltenes by quantitative pyrolysis-mass spectrometry. J Anal Appl Pyrol 20:25-45

Falcon RMS (1986) A brief review of the origin, formation, and distribution of coal in southern Africa. In: Anhaeusser CR, Maske S (eds) Mineral deposits of Southern Africa, vol I and II. Geological Society of South Africa, Johannesburg, pp 1879-1898

Falcon MS, Snyman CP (1986) An introduction to coal petrography: atlas of petrographic constituents in the bituminous coals of Southern Africa. Geological Society of South Africa, Johannesburg
Glasspool I (2003a) Palaeoecology of selected South African export coals from the Vryheid Formation, with emphasis on the role of heterosporous lycopods and wildfire derived inertinite. Fuel 82:959-970

Glasspool IJ (2003b) Hypautochthonous-allochthonous coal deposition in the Permian, South African, Witbank Basin No. 2 seam; a combined approach using sedimentology, coal petrology and palaeontology. Int J Coal Geol 53:81-135

Hagelskamp HHB, Snyman CP (1988) On the origin of low-reflecting inertinites in coals from the Highveld Coalfield, South Africa. Fuel 67:307-313

Han Z, Kruge MA, Crelling JC, Stankiewicz BA (1995) Organic geochemical characterization of the density fractions of a Permian torbanite. Org Geochem 22(1):39-50

Hartgers WA, Sinninghe Damste JS, de Leeuw JW, Ling Y, Dyrkacz GR (1994) Molecular characterization of flash pyrolyzates of two carboniferous coals and their constituting maceral fractions. Energy Fuels 8(5):1055-1067

Hatcher PG, Clifford DJ (1997) The organic geochemistry of coal: from plant materials to coal. Org Geochem 27(5-6):251-274

Hower JC, O'Keefe JMK, Watt MA, Pratt TJ, Eble CF, Stucker JD, Richardson AR, Kostova IJ (2009) Notes on the origin of inertinite macerals in coals: observations on the importance of fungi in the origin of macrinite. Int J Coal Geol 80(2):135-143

Hower JC, O'Keefe JMK, Eble CF, Raymond A, Valentim B, Volk TJ, Richardson AR, Satterwhite AB, Hatch RS (2011a) Notes on the origin of inertinite macerals in coal: evidence for fungal and arthropod transformations of degraded macerals. Int J Coal Geol $86(2-3): 231-240$

Hower JC, O'Keefe JMK, Eble CF, Volk TJ, Richardson AR, Satterwhite AB, Hatch RS, Kostova IJ (2011b) Notes on the origin of inertinite macerals in coals: funginite associations with cutinite and suberinite. Int J Coal Geol 85(1):186-190

Hower JC, O'Keefe JMK, Wagner NJ, Dai S, Wang X, Xue W (2013) An investigation of Wulantuga coal (Cretaceous, Inner Mongolia) macerals: paleopathology of faunal and fungal invasions into wood and the recognizable clues for their activity. Int $\mathrm{J}$ Coal Geol 114:44-53

International Committee for Coal and Organic Petrology (ICCP) (1998) The new vitrinite classification (ICCP system 1994). Fuel 77(5):349-358

International Committee for Coal and Organic Petrology (ICCP) (2001) The new inertinite classification (ICCP system 1994). Fuel 80(4):459-471

Jasper A, Guerra-Sommer M, Abu Hamad AMB, Bamford M, Cerruti Bernardes-de-Oliveira ME, Tewari R, Uhl D (2013) The burning of Gondwana: permian fires on the southern continent-a palaeobotanical approach. Gondwana Res 24(1):148-160

Kawamoto H (2017) Lignin pyrolysis reactions. J Wood Sci 63(2):117-132

Kruszewska KJ (2003) Fluorescing macerals in South African coals. Int J Coal Geol 54:79-94

Liu D, Peng P (2008) Possible chemical structures and biological precursors of different vitrinites in coal measure in Northwest China. Int J Coal Geol 75(4):204-212

Meuzelaar HLC, Harper AM, Hill GH, Given PH (1984) Characterization and classification of Rocky Mountain coals by Curiepoint pyrolysis mass spectrometry. Fuel 63(5):640-652

Moore TA, Shearer JC (1997) Evidence for aerobic degradation of Palangka Raya peat and implications for its sustainability. In: Rieley JO, Page SE (eds) Tropical peatlands. Samara Publishing Limited, Cardigan, pp 157-167

Moore TA, Shearer JC, Miller SL (1996) Fungal origin of oxidized plant material in the Palangkaraya peat deposit, Kalimantan Tengah, Indonesia: implications for 'inertinite' formation in coal. Int J Coal Geol 30:1-23 
Moroeng OM, Wagner NJ, Brand DJ, Roberts RJ (2018a) A nuclear magnetic resonance study: implications for coal formation in the Witbank coalfield, South Africa. Int J Coal Geol 188:145-155

Moroeng OM, Keartland JM, Roberts RJ, Wagner NJ (2018b) Characterization of coal using electron spin resonance: implications for the formation of inertinite macerals in the Witbank coalfield, South Africa. Int J Coal Sci Technol 5(3):385-398

Moroeng OM, Wagner NJ, Hall G, Roberts RJ (2018c) Using $\delta^{15} \mathrm{~N}$ and $\delta^{13} \mathrm{C}$ and nitrogen functionalities to support a fire origin for certain inertinite macerals in a No. 4 Seam Upper Witbank coal, South Africa. Org Geochem 126:23-32

Nip M, De Leeuw JW, Schenck PA (1988) The characterization of eight maceral concentrates by means of Curie point pyrolysisgas chromatography and Curie point pyrolysis-gas chromatography-mass spectrometry. Geochim Cosmochim Acta 52(3): 637-648

Nip M, De Leeuw JW, Crelling JC (1992) Chemical structure of bituminous coal and its constituting maceral fractions as revealed by flash pyrolysis. Energy Fuels 6(2):125-136

Odden W, Barth T (2000) A study of the composition of light hydrocarbons $\left(\mathrm{C}_{5}-\mathrm{C}_{13}\right)$ from pyrolysis of source rock samples. Org Geochem 31(2-3):211-229

O'Keefe JMK, Bechtel A, Christanis K, Dai S, DiMichele WA, Eble CF, Esterle JS, Mastalerz M, Raymond AL, Valentim BV, Wagner NJ, Ward CR, Hower JC (2013) On the fundamental difference between coal rank and coal type. Int J Coal Geol 118:58-87

Okolo GN, Neomagus HWJP, Everson RC, Roberts MJ, Bunt JR, Sakurovs R, Mathews JP (2015) Chemical-structural properties of South African bituminous coals: insights from wide angle XRD-carbon fraction analysis, ATR-FTIR, solid state ${ }^{13} \mathrm{C}$ NMR, and HRTEM techniques. Fuel 158:779-792

Phiri Z, Everson RC, Neomagus HWJP, Wood BJ (2018) Transformation of nitrogen functional forms and the accompanying chemical-structural properties emanating from pyrolysis of bituminous coals. Appl Energy 216:414-427

Pickel W, Kus J, Flores D, Kalaitzidis S, Christanis K, Cardott BJ, Misz-Kennan M, Rodrigues S, Hentschel A, Hamor-Vido M, Crosdale P, Wagner N, ICCP (2017) Classification of liptiniteICCP system 1994. Int J Coal Geol 169:40-61

Powell TG, Boreham CJ, Smyth M, Russell N, Cook AC (1991) Petroleum source rock assessment in non-marine sequences: pyrolysis and petrographic analysis of Australian coals and carbonaceous shales. Org Geochem 17(3):375-394

Roberts MJ, Everson RC, Neomagus HWJP, Van Niekerk D, Mathews JP, Branken DJ (2015) Influence of maceral composition on the structure, properties and behaviour of chars derived from South African coals. Fuel 142:9-20

Scott AC (1989) Observations on the nature and origin of fusain. Int J Coal Geol 12:443-475

Scott AC (2002) Coal petrology and the origin of coal macerals: a way ahead? Int J Coal Geol 50:119-134

Scott AC (2010) Charcoal recognition, taphonomy and uses palaeoenvironmental analysis. Palaeogeogr Palaeoclimatol Palaeoecol 291:11-39

Senftle JT, Larter SR (1987) Comparative geochemistry of vitrinite kerogens from Carboniferous and Tertiary provinces. Org Geochem 11(5):407-409
Senftle JT, Larter SR, Bromley BW, Brown JH (1986) Quantitative chemical characterization of vitrinite concentrates using pyrolysis-gas chromatography, rank variation of pyrolysis products. Org Geochem 9(6):345-350

Snyman CP (1989) The role of coal petrography in understanding the properties of South African coal. Int J Coal Geol 14:83-101

Solum M, Pugmire RJ, Grant DM (1989) ${ }^{13}$ C Solid-state NMR of argonne premium coals. Energy Fuels 3:187-193

South African National Standards (SANS) 17246:2011 (ISO 17246:2010). Coal-Proximate analysis

South African National Standards (SANS) 17247:2006 (ISO 17247:2005). Coal-Ultimate analysis

South African National Standards (SANS) 334:1992 (ISO 334:1992). Solid mineral fuels-determination of total sulfur-Eschka method

South African National Standards (SANS) 7404-2:2015 (ISO 7404-2:2009). Methods for the petrographic analysis of coals Part 2: methods of preparing coal samples

South African National Standards (SANS) 7404-3:2016 (ISO 7404-3:2009). Methods for the petrographic analysis of coalsPart 3: method of determining maceral group

South African National Standards (SANS) 7404-5:2016 (ISO 7404-5:2009). Methods for the petrographic analysis of coalsPart 5: method of determining microscopically the reflectance of vitrinite

South African National Standards (SANS) 7936:2010 (ISO 7936:1992) Hard coal-Determination and presentation of float and sink characteristics—general directions for apparatus and procedures

Suggate RP, Dickinson WW (2004) Carbon NMR of coals: the effects of coal type and rank. Int J Coal Geol 57:1-22

Sun Y, Horsfield B (2005) Comparison of the geochemical characteristics of "barkinite" and other macerals from the Dahe mine, South China. Energy Explor Exploit 23(6):475-494

Taylor GH, Teichmüller M, Davis A, Diessel CFK, Littke R, Robert P (1998) Organic petrology. Gebrüder Borntraeger, Berlin, p 704

Teichmüller M (1989) The genesis of coal from the viewpoint of coal petrology. Int J Coal Geol 12:1-87

Valentim B, Algarra M, Guedes A, Ruppert LF, Hower JC (2016) Notes on the origin of copromacrinite based on nitrogen functionalities and $\delta^{13} \mathrm{C}$ and $\delta^{15} \mathrm{~N}$ determined on samples from the Peach Orchard coal bed, southern Magoffin County, Kentucky. Int J Coal Geol 160-161:63-72

van Krevelen DW (1993) Coal: typology, chemistry, physics, constitution, 3rd edn. Elsevier, Amsterdam, p 979

Van Niekerk D, Pugmire RJ, Solum MS, Painter PC, Mathews JP (2008) Structural characterization of vitrinite-rich and inertiniterich Permian-aged South African bituminous coals. Int J Coal Geol 76:290-300

Veld H, de Leeuw JW, Sinninghe Damsté JS, Fermont WJJ (1994) Molecular characterization of vitrinite maturation as revealed by flash pyrolysis methods. In: Mukhopadhyay PK, Dow WG (eds) Vitrinite reflectance as a maturity parameter: applications and limitations, ACS symposium series 570. American Chemical Society, Washington DC, pp 149-160

Zieger L, Littke R, Schwarzbauer J (2018) Chemical and structural changes in vitrinites and megaspores from Carboniferous coals during maturation. Int J Coal Geol 185:91-102 